\title{
Pinisi Discretion Review
}

Volume 3, Issue 1, September, 2019 Page. 13- 20

ISSN (Print): 2580-1309 and ISSN (Online): 2580-1317

\section{The Effectiveness of Earth and Building Tax Collection in Takalar District}

\author{
Irfan $^{1}$, Jumalia Mannayong ${ }^{2}$, Haerul ${ }^{3}$ \\ ${ }^{1,2}$ Sekolah Tinggi Ilmu Administrasi Negara Makassar \\ ${ }^{3}$ Universitas Negeri Makassar \\ E-mail: Irfantulo_77@yahoo.co.id
}

(Received: February-2019; Reviewed: April-2019; Accepted: June-2019;

Avalaibel Online: August 2019; Published: September-2019)

c) (7) (8) This is an open access article distributed under the Creative Commons Attribution License

EY CC-BY-NC-4.0 (C2019 by author (https://creativecommons.org/licenses/by-nc/4.0/)

\begin{abstract}
Regional autonomy gives the region the right to determine its own direction and development goals in the area. This research aims to analyze and discuss the Effectiveness of Land and Building Tax Collection in Takalar Regency. The research method used is qualitative with a Case Study approach. Data Collection and Validation Techniques are carried out by; observation, interview, and documentation. The data analysis technique used in this study is the analysis that is carried out continuously both in the process of collecting data and after the data collection has been completed. The data analysis process used in this study is data condensation, data display, and conclusion drawing/verifications. The results of the study are based on the Source Approach of the Takalar District Financial Management Agency in terms of human resources and the source of facilities and infrastructure which are considered to be still relatively low/insufficient in the management of increased PBB collection.
\end{abstract}

Keywords: Effectiveness; tax; PBB

\section{INTRODUCTION}

National Development is an ongoing and continuous activity aimed at improving the welfare of the people. In the administration of governance and national development, Indonesia adheres to the principle of decentralization by providing opportunities for regional governments in carrying out regional autonomy.(Undang-Undang Nomor 23 Tahun 2014 tentang Pemerintahan Daerah, 2014) mandating that all local government affairs be left to the regional government, the region is now given full authority to plan, implement, monitor, control and evaluate regional policies. broader, real and responsible authority to the autonomous region to regulate and manage their own government affairs and exercise authority on their own initiative in accordance with the interests of the local community and the potential of each region based on statutory regulations. 
Regional autonomy gives the region the right to determine its own direction and development goals in the region (Amin, 2013; Dewanta, 2004; Kuncoro, 2004). This occurs as a consequence of the surrender of central government authority to the regional government in full to take care of their own regional households, the development in the region is considered capable if the regions themselves handle it. With autonomy, local governments are given the opportunity to manage regional own-source revenues (Hamid, 2001; Nadir, 2013; Pendidikan, Sosial Budaya, \& Saifuddin, 2001; Rinaldi, 2013). Regions already have full authority to be able to explore potential sources of income to support development implementation. The implementation of regional autonomy is intended so that the regions can develop according to their own abilities. Therefore, serious efforts need to be made by the regency to improve its regional finances. Without good financial income, the regions are not able to carry out the responsibilities and authority in managing and managing their households to the fullest (Abdullah, 2004; Mahmudi, 2010; Wati, Herawati, \& Sinarwati, 2014).

One source of regional funding according to (Undang-undang nomor 33 tahun 2004 tentang Dana Perimbangan antara Pemerintah Pusat dan Pemerintah Daerah, 2004) explained that the regional original revenue is one of the sources of regional finance, every government activity both the main task and the task of assistance can be carried out effectively and efficiently if it is balanced by the presence of local revenue, as one of the sources of driving government programs. With the regional original revenue, it will minimize the dependence of the region on central assistance. Therefore, the regions will be given the authority to explore the potential of their respective regions for genuine regional income. Original sources of income according to (Undang-undang nomor 33 tahun 2004 tentang Dana Perimbangan antara Pemerintah Pusat dan Pemerintah Daerah, 2004). Consists of several components, namely local taxes, regional levies, and others. Legitimate local original income. Where has the biggest contribution to local original income, regional tax. Tax is a levy from the public by the State (government) based on laws that are enforceable and indebted to the taxpayer, pays by not getting a direct return, the results of which are used to finance state expenditure in the administration and development. However, as explained above that regions depend on their respective financial management, this can be our measurement tool in seeing how the current government in managing central and regional finances that still has some shortcomings. One example is the various potentials of local revenue that have not been maximally managed by the local government, especially the Regional Financial Management Agency of Takalar District, which has an important role in the development of the region.

There are several types of taxes levied by the Takalar District Government including street lighting tax, advertisement tax, land, and building tax, restaurant tax, hotel tax, entertainment tax, class $C$ excavation tax, as well as underground water taxes. One type of taxmanaged by the Regional Financial Management Agency of the Takalar district is the Land and Building Tax for Rural and urban areas which are considered to have potentials that are not yet managed. Based on the law, one source of local revenue is the land and rural and urban building tax, the land and rural and urban building tax is a tax on land and buildings that are owned, controlled and / or utilized by individuals or entities, except areas that are used for plantation, forestry and mining business activities

The regional government of Takalar Regency has implemented the regulation for the past 1 (one) year, whereby the regional government manages the UN fully based on the established regulations. Takalar Regency's Rural and Urban Land and Building Tax is regulated in (Peraturan Daerah Nomor 08 Tahun 2012 tentang Pajak Daerah, 2012) that which is included in the definition of buildings, namely environmental roads, toll roads, swimming pools, luxury fences, sports venues, shipyards, jetties, luxury parks, oil storage / refineries, water and gas, oil pipes and towers. The rural and urban land and building tax should be potential enough to 
influence the increase in Takalar Regency's Original Revenue because the rural and urban land and building tax is the type of tax that has the most basic number of taxpayers. However, the realization of rural and urban land and building tax receipts in Takalar District in recent years did not reach the targeted amount. It can be seen from 2011 to 2013 . The revenue presentation in 2011 was $76.78 \%$ or $(2,514,270,557)$, in 2012 as many as $66.57 \%$ or $(2,399,561,607)$ while in 2013 as many as $73.32 \%$ or $(2,817,589,524)$.

The Land and Building Tax (PBB) as the legal basis is Law Number 12 of 1985 which has been amended to Law Number 12 of 1994 and the last is Law Number 28 of 2009 concerning Land and Building Tax. Land and Building Tax (PBB) is one of the tax reform policies in 1985. Land and Building Tax there are 5 types which are abbreviated to P2 and P3. PB P2 itself is the UN rural and urban sector while the UN P3 is the UN plantation, fisheries and mining sector. The earth and buildings are two objects of the United Nations, namely the earth which can be defined as the surface of the earth in the form of land and water and everything below it, while the building is a technical construction that is implanted or permanently attached to land and waters in the territory of Indonesia. To overcome these deficiencies, some administrative improvements need to be made such as improving the database, expanding the base, intensifying and extending the taxpayers/levies, and needing to improve the quality of the local government apparatus.

The Tax Collecting Officer (Local-Village / Kelurahan / Kecamatan / City / Regency Government) evaluates the Taxpayer Data (voluntarily-so quickly) by classifying the type of problem (as mentioned above); if you can use the most recent shared data (DHKP and SPPT) from the Tax Service office (for the writer's area it is usually distributed in April).

The effectiveness of land and building tax is very much needed in the implementation and also its management. Especially in supporting infrastructure development in the area of Takalar Regency. So that the welfare of the community can be increased and the accesses needed to grow the economy and welfare of the community can be fulfilled properly.

The above phenomenon illustrates the gap between expectations and reality (Das Sollen and Das Sein) in the implementation of regional revenue management. Therefore, it attracts the attention of researchers to conduct research under the title "Analysis of Land and Building Tax Collection in Takalar District".

\section{METHOD}

This type of research is a type of qualitative research, this is done to analyze in-depth the phenomenon of the United Nations collection problem. Qualitatively, this research can and is able to describe the actual situation (naturalistic) in the field. This study uses a Case Study approach, the Phenomenology Approach is used as an approach in this study because this research explores the pattern of collecting Land and Building Taxes. Thus this study seeks to understand the meaning of events, as well as the interaction of people or individuals in certain situations. The phenomenological approach requires a number of different assumptions in the manner used to approach people's behavior with the intention of discovering "facts" or "causes". Sources of data in this study basically use two types of data namely; primary data and secondary data in proportion to the objectives to be achieved in this study. Primary data obtained through interviews with informants and observations while secondary data obtained through documents, reports on research results and regulations governing the policy of implementing the United Nations collection 


\section{RESULT AND DISCUSSION}

Dasar hukum pajak adalah UUD 1945 pada pasal 23 yang mengatur tentang keuangan negara terutama pasal 23A yang berbunyi "Pajak dan pungutan lain yang bersifat memaksa untuk keperluan negara diatur dengan Undang-Undang. Sehingga dapat ditarik kesimpulan bahwa pasal 23A UndangUndang Dasar 1945 merupakan dasar hukum dari semua peraturan perpajakan yang berlaku di Indonesia. Kemudian (Undang-Undang No. 16 Tahun 2009 tentang Ketentuan Umum dan Tata Cara Perpajakan, 2009)

\section{Source Approach}

The success of an organization or institution is largely determined by the resources both human resources and the resources of facilities and infrastructure and related to the focus of his research as a taxpayer acceptance, of course paying attention to taxpayer resources.

Planning is the first step in implementing an activity as well as in managing the Rural and Urban Land and Building Tax carried out by the Regional Financial Management Agency. Where the planning referred to is all the processes carried out in preparing plans in the management of PBB-P2 which are based on applicable regulations namely Takalar regional regulation number 08 of 2012 on local taxes and Takalar Regent regulation number 32 of 2014 concerning duties and functions of office structural Takalar Regency Regional Financial Management Agency.

As a first step of course planning is very much on the results to be achieved. Planning is the basis for moving on to the next activity. Planning in the management of PBB-P2 which includes determining targets and socializing Tax Registration Mechanisms and Procedures. The following are the results of research conducted on PBB-P2 tax planning.

In the planning, the local government office takes the first step, which is determining targets. Determination of targets is a must, the targets to be achieved every region per year in determining regency original revenue by the Regional Financial Management Agency are then discussed and determined through a plenary meeting every fiscal year.

Through the approach to resources at the Takalar District Financial Management Agency seen from human resources, in this case, the level of education is good because the average employee has a high level of education but needs to be done intensively training because there is still not enough training, given education and training it is very important not only for the development of human resources quality in knowledge but also can improve employee performance which certainly can have a good impact on tax revenue, so also the quantity of human resources in this office is still lacking especially in the land and building tax section. Facilities and infrastructure in this office are also still incomplete. But when viewed from the awareness of taxpayers in paying taxes is very minimal. This can be seen in the table below:

Table 1.

Target and Realization of PBB-P2 Takalar Regency

\begin{tabular}{ccccc}
\hline Year & Tax Payer & Target & Realization (Rp) & Percentage (\%) \\
\hline 2015 & 165691 & $3,851,918,750$ & $2,904,604,184$ & 75,41 \\
2016 & 167132 & $3,817,117,088$ & $2,626,676,807$ & 68,81 \\
2017 & 167964 & $3,872,369,855$ & $2,756,902,983$ & 71,19 \\
\hline
\end{tabular}

Source: Income Office Region, Takalar Regency, 2018 
Based on the above data presentation, it is seen that for three consecutive years the target set did not experience a significant increase. This shows that there is still a lack of government efforts to increase regional income in the region's original revenue through the Rural and Urban Land and Building Tax.

\section{Process Approach}

The tax paid is then reported by the appointed apparatus, and reported to the relevant office to the local treasury no later than $1 \times 24$ hours or within a period determined by the regent or official. From the results of the interview above, it shows that there is a lack of attention to the management of the United Nations tax, in which the field assigned to manage the tax in the division of tasks is not carried out specifically, it is better for each sector to supervise one tax.

Taxpayers who are negligent or deliberately do not pay taxes, the officers take a variety of ways, especially issuing letters of reprimand and even forced summons. Through the Process Approach of a number of programs carried out at the Takalar District Financial Management Agency, there are several programs that have not been carried out effectively including tax data re-registration. In this case, the BPKD has not maximized data collection on tax object taxpayers every year even though this data collection is important because with BPKD taxpayer re-registration the taxpayer will know the number of taxpayers and tax objects that have increased and this certainly can increase land tax revenue each the year. Likewise with active billing through forced letters and reprimands, in the active billing BPKD has not done it well because so far only letters of reprimand given to taxpayers are in arrears even though from the time of arrears the taxpayers should have been given forced letters such as those already contained in the law. Similarly, the determination of revenue targets in accordance with the real conditions so far BPKD has not set a target of land and building tax revenues in accordance with real conditions.

\section{Target Approach}

Land and Building Tax Revenue is one of the most important things in the continuity of development and economic development in a region, therefore the back and forth of Sautu Daera depends on the governance of tax revenue from taxpayers. To find out the target achievement of tax revenue, an evaluation or supervision is conducted.

If deviations are found, the supervisory team has the right to give warnings to taxpayers. One of the most frequently encountered problems when monitoring in the field is that some taxpayers do not pay their taxes on time.

The problem of taxpayers who do not pay taxes until maturity is then processed to be followed up by visiting taxpayers who are lazy to pay taxes.

Letter of reprimand and warning or other similar letters as the initial act of carrying out tax collection issued 7 days from the time of payment due. If within 7 days after the warning the taxpayer is obliged to pay off the tax owed. Taxpayers who do not follow these regulations are then followed up with administrative sanctions. Administrative sanctions by paying interest of $2 \%$ every month for a maximum of 15 months from the time of debt.

Based on the description of the results of interviews by several informants, according to the government of the Takalar Regency Regional Financial Management Agency in the management of the United Nations based on the management functions of planning, implementation, and supervision in accordance with the main tasks and functions of the Agency it can be concluded that the management of the United Nations in increasing PAD has not been maximized or has not yet reached target, this is because there are still some constraints that 
prevent the government from exploring the potentials and increasing PAD. Therefore the government should pay more attention to these obstacles and also pay attention to factors that support the increase in regional income.

\section{CONCLUSION}

The results of this study indicate that the development of employee competencies as a whole is in a good category when viewed from the aspects of competence, motives, encouragement of economic needs, character, self-concept, knowledge, and skills.

\section{REFERENCES}

Abdullah, S. (2004). Akuntansi Sektor Publik Akuntansi Keuangan Daerah. Kinerja Journal of Business and Economics.

Amin, I. D. (2013). Otonomi Daerah Untuk Penguatan Negara Kesatuan Republik Indonesia ( Pengelolaan Keuangan dalam Pelaksanaan Otonomi Daerah ). Jurnal Ilmiah Mahasiswa. https://doi.org/10.4103/1673-5374.228722

Amstrong, M., \& Baron, A. (1998). Performance Management. London: Institute of Personnel and Development.

Becker, B. E., \& Huselid, M. A. (2006). Strategic human resources management: Where do we go from here? Journal of Management. https://doi.org/10.1177/0149206306293668

Dewanta, A. S. (2004). Otonomi dan Pembangunan Daerah. Unisia. https://doi.org/10.20885/unisia.vol27.iss53.art12

Hamid, A. (2001). Otonomi Daerah dan Kualitas Pelayanan Publik. Buletin Pengawasan.

Kuncoro, M. (2004). Otonomi Daerah dan Pembangunan Daerah: Reformasi, Perencanaan, Strategi, dan Peluang. In Unisia. https://doi.org/10.20885/unisia.vol27.iss53.art12

Mahmudi. (2010). Manajemen Keuangan Daerah. In dalam pelaksanaan otonomi daerah dan desentralisasi fiskal, pemerintahan dituntut untuk memiliki kenandirian keuangan daerah yang lebih besar. Dengan tingkat kemandirian keuangan yang lebih besar berarti daerah tidak akan lagi sangat bergantung pada bantu.

Mangkunegara, A. A. A. P. (2003). Manajemen Sumber Daya Manusia Perusahaan. In Remaja Rosdakarya. https://doi.org/10.1038/cddis.2011.1

Nadir, S. (2013). Otonomi Daerah dan Desentralisasi Desa. Jurnal Politik Profetik. https://doi.org/10.24252/jpp.v1i1.1621

Pendidikan, O., Sosial Budaya, P., \& Saifuddin, A. F. (2001). Kebijakan Otonomi Daerah. Antropologi Indonesia. https://doi.org/10.1080/03323315.2013.798524

Peraturan Daerah Nomor 08 Tahun 2012 tentang Pajak Daerah. Peraturan Daerah Nomor 08 Tahun 2012 tentang Pajak Daerah. , (2012).

Riani, A. L. (2011). Budaya Organisasi (Cetakan Pe). Yogyakarta: Graha Ilmu. 
Rinaldi, U. (2013). Kemandirian Keuangan Dalam Pelaksanaan Otonomi Daerah. Jurnal EKSOS.

Robbins, S. P., \& Coulter, M. (2012). Management. In Pearson.

Sedarmayanti. (2011). Tata Kerja dan Produktivitas Kerja. In Bandung, CV Mandar Maju.

Sedarmayanti. (2017). Manajemen Sumber Daya Manusia. In Manajemen Sumber Daya Manusia.

Silalahi, U. (2015). Asas-Asas Manajemen. Refika Aditama.

Sudarmanto. (2015). Kinerja dan Pengembangan Kompetensi SDM. In Kinerja dan Pengembangan Kompetensi SDM.

Undang-Undang No. 16 Tahun 2009 tentang Ketentuan Umum dan Tata Cara Perpajakan. Undang-Undang No. 16 Tahun 2009 tentang Ketentuan Umum dan Tata Cara Perpajakan., (2009).

Undang-Undang Nomor 23 Tahun 2014 tentang Pemerintahan Daerah. Undang-Undang Nomor 23 Tahun 2014 tentang Pemerintahan Daerah. , (2014).

Undang-undang nomor 33 tahun 2004 tentang Dana Perimbangan antara Pemerintah Pusat dan Pemerintah Daerah. Undang-undang nomor 33 tahun 2004 tentang Dana Perimbangan antara Pemerintah Pusat dan Pemerintah Daerah., (2004).

Wati, K. D., Herawati, N. T., \& Sinarwati, N. K. (2014). Pengaruh Kompetensi SDM, Penerapan SAP, dan SAKP terhadap Kualitas Laporan Keuangan Daerah. e-journal S1 Ak Universitas pendidikan ganesha.

Wibowo. (2007). Manajemen Kinerja. Jakarta: Raja Grafindo Persada.

Wilhelm, P. G. (1989). Controlling Work Stress: Effective Human Resource and Management Strategies. Academy of Management Review. https://doi.org/10.5465/amr.1989.4279083 
Pinisi Discretion Review

Volume 3, Issue 1, September, 2019. Pages 13-20 